\title{
Argentinean peanut sauce similar to mayonnaise: chemical, nutritional and sensorial aspects
}

\author{
By M.Guadalupe Johnston, Verónica M. Navarro, Nilda I. Brutti, Valeria Nepote, Nelson R. Grosso \\ and Carlos A. Guzmán*
}

Instituto de Ciencia y Tecnología de los Alimentos- Facultad de Ciencias Exactas, Físicas y Naturales- IMBIV-CONICET- Universidad Nacional de Córdoba- Av. Vélez Sarsfield 1600, (5016)- Córdoba- Argentina. Tel-fax:54-351-4334439.

e-mail: icta@gtwing.efn.uncor.edu

\section{RESUMEN}

Salsa de maní argentino similar a la mayonesa: aspectos químicos, nutricionales y sensoriales.

La propuesta de este estudio fue preparar un aderezo usando maní blanchado (pelado) argentino, que tenga un aspecto similar a la mayonesa y que tenga características de un alimento sano. La composición porcentual, los ácidos grasos y la estabilidad oxidativa del producto fueron determinadas y comparadas con mayonesa comercial y aceite de girasol. Además un test de aceptabilidad fue realizado sobre dicho producto. Los resultados mostraron mejores cualidades nutricionales en la mayonesa de maní debido a que tiene un menor contenido calórico y graso y una mayor proporción de ácidos grasos monoinsaturados que los otros aderezos. Este producto contiene fibras y vitamina $\mathrm{E}$, carece de colesterol y tiene baja concentración de sodio. La estabilidad oxidativa de los lípidos fue similar a la de la mayonesa comercial y al aceite de girasol. Respecto a sus propiedades sensoriales, la mayonesa de maní fue considerada aceptable por el 71,7 \% de los consumidores. Este producto responde a las características de un alimento sano y puede ser usado para varios propósitos.

PALABRAS-CLAVE: Aceptabilidad - Ácidos grasos - Calidad nutricional - Maní - Mayonesa.

\section{SUMMARY}

Argentinean peanut sauce similar to mayonnaise: chemical, nutritional and sensorial aspects.

The purpose of this study was to prepare a dressing using blanched Argentinian peanuts, that looks like mayonnaise and that has a patterns of a healthy nourishment. The general composition of the product, as well as the fatty acid composition and stability to oxidation were determined and compared to standard commercial mayonnaise and sunflower oil. A consumer test was performed on the product. The results showed a better nutritional quality of the peanut mayonnaise, due to a lower fat and caloric contents and a higher mono-unsaturated proportion of fatty acids than the other dressings. This product contains fiber and vitamin $\mathrm{E}$, it lacks cholesterol and is low in sodium. The stability to lipid oxidation was similar to that of standard commercial mayonnaise and sunflower oil. Concerning sensorial aspects, the product was well accepted by $71.7 \%$ of the consumer panelists. It responds to healthy-food guidelines and can be used for various purposes.

KEY-WORDS: Acceptability - Fatty acids - Mayonnaise -Nutritional quality - Peanut.

\section{INTRODUCTION}

In Argentina, the mortality due to cardiovascular diseases (CVD) has a predominance of $36.7 \%$, over other causes of death (Organización Panamericana de la Salud, 2000). The structure of the typical familiar food consumption in this country strongly indicates that there is a high ingestion of meats and fats of animal origin; as a consequence, the consumption of saturated fats and cholesterol is elevated (Dixon and Ernest, 2001). Food containing a high amount of total fats, saturated fats, trans-fatty acids, cholesterol, oxysterol and simple carbohydrates, constitute a risk factor for CDV and other chronic diseases (Olivares, 1996). Healthy foods can contribute to improve the quality of life to people.

As a rule, saturated fatty acids produce an increment in the plasma levels of LDL and HDL; however, lauric (C12), myristic (C14) and palmitic (C16) acids are the most atherogenic ones, whereas short, medium C8 and C10 chain and stearic acids, lack such effect (Raatz et al., 2001). Polyunsaturated fatty acids can produce a moderate reduction in the levels of cholesterol and LDL, although they present the inconvenience of being easily oxidizable. Mensink and Katan (1992) suggested that monounsaturated fatty acids exert either a neutral or a minor effect on total cholesterol as compared to PUFAs. On the contrary, Mattson and Grundy (1985) demonstrated that MUFAs reduce the levels of both total cholesterol and LDL. Furthermore, MUFAs are less susceptible to oxidation than PUFAs and their ingestion does not diminish the plasma levels of HDL (Mensink and Katan, 1992; Cicchitti, 1996; FAO, 1992; Mahan and Arlin, 1996; Krauss et al., 1996).

The province of Córdoba (Argentina) is the main producer of peanut in Argentina (Harvez, 1996). As a difference with other countries, like U.S.A., in which many products have been developed from this source, in Argentina these seeds are mainly used for the extraction of oil, manufacturing of pellets and direct consumption (CIARA, 2000). Peanut seeds, 
besides being a low-cost product, are an excellent source of nutriments, since it contains a very high proportion of mono- and polyunsaturated fatty acids, such as oleic (C18:1) and linoleic (C18:2) ones, respectively, as well as proteins, carbohydrates, vitamins, minerals and fiber (Ahmed and Young, 1982; Grosso y Guzmán, 1995).

The elaboration of highly consumed foods but with better nutritional characteristics than traditional ones provides an interesting alternative to the habitual diet, and also, a new tool for the prevention of certain chronic diseases. The objective was: to develop a mayonnaise from peanut (PM) that respond to the patterns of a healthy nourishment and to evaluate its chemical composition, nutritional supply, stability and its degree of acceptability by people.

\section{EXPERIMENTAL}

\subsection{Materials}

The product was similar to mayonnaise but it did not have eggs, therefore, the authors decided to call this product "peanut mayonnaise" between quotation marks through the text.

The basic "peanut mayonnaise" (PM) used in this work was elaborated with: $100 \mathrm{~g}$ of blanched argentinian peanuts (1997 crop year, Córdoba, Argentina), $70 \mathrm{~mL}$ sunflower oil, $50 \mathrm{~mL}$ lemon juice, 2 $\mathrm{g}$ salt $(\mathrm{NaCl}), 6 \mathrm{~g}$ lecithin, $4 \mathrm{~g}$ mustard (Fanacoa, Refinería de Maíz, Escobar, Buenos Aires, Argentina), 6 drops of Bixa orellana pigment, $20 \mathrm{mg}$ of butyl-hydroxy-toluene (BHT), and $20 \mathrm{~mL}$ of distilled water.

The standard commercial mayonnaise (Fanacoa, Refinería de Maíz, Pilar, Buenos Aires, Argentina) was used as a reference sample. According to the information contained in the manufacturer's label, the commercial mayonnaise $(\mathrm{CM})$ was elaborated with: water, oil, vinegar, starch, egg yolk, salt, lemon juice, sugar and dextrose monohydrate.

Preparation of "peanut mayonnaise". The blanched peanuts were cooked in a steam under pressure during 45 minutes until the grains were very tender and then they were drained and ground to a paste during 5 minutes using a food processor grinder (Cuisinart-Original, model DLC-10C TX, Cuisinart, East Windsor, NJ, USA). Afterwards, it was homogenized with sunflower oil (O) during 3 minutes in a blender and then the other ingredients were incorporated. After being homogenized once more, it was packed in hermetic glass jars with lids.

\subsection{Chemical analyses}

The percentage of proteins was determined by the method of Kjeldahl (AOAC, 1980). The factor 5.46
(Young and Hammons, 1973) was employed to convert nitrogen into proteins. Lipids were determined by continuous extraction using petroleum ether (boiling range $30-60^{\circ} \mathrm{C}$ ) in soxhlet for 12 hours (Grosso and Guzmán, 1995). Humidity was established by drying in a oven at $60{ }^{\circ} \mathrm{C}$ until weight was constant. The ashes were determined by incineration in a muffle at $550-600{ }^{\circ} \mathrm{C}$ for 6 hours (Maldonado and Guzmán, 1982). The fiber was determined by an enzymatic-gravimetric test (AOAC, 1990), and carbohydrates by the difference using the formula: $\%$ carbohydrates $=100 \mathrm{~g}$ mayonnaise $-(\%$ lipids $+\%$ proteins $+\%$ ashes $+\%$ humidity). Vitamins and minerals were estimated in a theoretical way using tables containing the chemical composition of nutriments (Universidad de Granada, 1995).

Fatty acid composition: the fatty acid methyl esters were prepared by transmethylation with a $3 \%$ solution of sulfuric acid in methanol, as previously described (Jellum and Worthington, 1966). The fatty acid methyl esters of total lipids were analyzed on a Shimadzu GC-R1A gas chromatograph equipped with flame ionization detector (FID). An AT-WAX superox II capillary column ( $30 \mathrm{~m}$ x $0.25 \mathrm{~mm}$ i.d.) was used. Column temperature was programmed from $180{ }^{\circ} \mathrm{C}$ (held for 10 minute) to $240^{\circ} \mathrm{C}\left(4^{\circ} \mathrm{C} / \mathrm{min}\right)$. Injector and detector temperatures were $250^{\circ} \mathrm{C}$ and $350^{\circ} \mathrm{C}$, respectively. The carrier (nitrogen) had a flow rate of $1 \mathrm{~mL} / \mathrm{min}$. A standard fatty acid methyl ester mixture (Sigma Chemical Co.) was used to identify sample peaks. Quantitative analysis of the fatty acids were performed using the heptadecanoic acid methyl ester as internal standard.

\subsection{Stability}

The peroxides value of each sample was measured after carrying out an accelerated oxidation of PM, CM and $\mathrm{O}$ in a oven at $60^{\circ} \mathrm{C}$ for 7 days (Keefe and Willey, 1993). All determinations were made by triplicate.

\subsection{Sensorial evaluation}

A panel of consumers $(n=100)$ was given a sample of PM and a survey consisting of an acceptability test. Each member of the panel had to render his or her general opinion of the product, according to a hedonic scale of 5 points where $1=$ dislike very much and $5=$ like very much (Anzaldua-Morales, 1994).

\subsection{Statistics}

The averages were compared by means of the student's " $t$ " test. When more than two samples were compared, an analysis of variance was employed and Duncan's test was used to determine mean differences. 


\section{RESULTS AND DISCUSSION}

"Peanut mayonnaise" had a series of nutritional properties that adjust to current feeding patterns, being fat the principal nutriment involved. Indeed, PM contained $6.9 \%$ carbohydrates; $5.8 \%$ proteins; 1.8 $\%$ fiber; $1.2 \%$ ashes; $41.4 \%$ humidity and $42.9 \%$ fats (Table I).

Although fats should be included in the diet, since they perform important biological functions in the organism, it has been demonstrated that an excess of lipids and calories in the diet is associated with an augmented incidence of obesity, cardiovascular diseases and certain types of cancer (Araya, 1996; FAO/WHO, 1997; Dixon and Ernest, 2001). PM had less fat $(44 \%, p<0.05)$ and calories $(37 \%)$ than $C M$, as well as a significantly greater amount of proteins, carbohydrates and humidity $(\mathrm{p}<0.05)$ (Table I).

Upon comparison of the nutriments contained in $30 \mathrm{~g}$ of PM -daily suggested intake- with the recommendations for a $2000 \mathrm{cal}$ diet, it is clear that this product supplies (percent): proteins $2.7 \%$; daily fiber $2.4 \%$; carbohydrates $0,75 \%$; calories $6.5 \%$; besides, niacin $13.4 \%$; Vit E $50 \%$ and sodium only $0.3 \%$, these three last ones estimated theoretically (Food and Nutrition Board, 1989). Thus, PM exhibited differences with regard to $\mathrm{CM}$ and $\mathrm{O}$, which contained almost exclusively lipids, constituting a better balanced fatty dressing (Table II).

"Peanut mayonnaise" contained a significant $(p<0.05)$ lower proportion of polyunsaturated fatty acids (PUFAs) and a higher quantity of monounsaturated fatty acids (MUFAs) and saturated fatty acids (SFAs) than CM and O (Table III). Both MUFAs and PUFAs were present in a significantly greater proportion than SFAs in PM, CM and O. Only $5.4 \%$ of daily requirements of SFAs could be supplied by $30 \mathrm{~g}$ PM. The highest oleic acid/linoleic acid ratio corresponded to $\mathrm{PM}$, due to the lipid composition of peanut.

The stability of the products under study to the oxidation of fats was determined through
Table I

General composition and fiber content of "peanut mayonnaise" (PM), standard commercial mayonnaise $(\mathrm{CM})$ and sunflower oil $(\mathrm{O})$

\begin{tabular}{lcccc}
\hline \multirow{2}{*}{ Composition } & \multicolumn{3}{c}{ Percentage $(\text { wt\% })^{\mathrm{a}}$} & p value \\
\cline { 2 - 4 } & P M & C M & O & \\
\hline Fats $^{\mathrm{b}}$ & $42.9 \mathrm{a}$ & $76.09 \mathrm{~b}$ & $100 \mathrm{c}$ & 0.001 \\
Proteins $^{\mathrm{C}}$ & $5.85 \mathrm{a}$ & $0.71 \mathrm{~b}$ & - & 0.001 \\
Ashes $^{\mathrm{C}}$ & $1.16 \mathrm{a}$ & $1.16 \mathrm{a}$ & & 1.000 \\
Carbohydrates $^{\mathrm{C}}$ & $6.89 \mathrm{a}$ & $1.61 \mathrm{~b}$ & - & 0.001 \\
Humidity $^{\mathrm{C}}$ & $41.4 \mathrm{a}$ & $20.45 \mathrm{~b}$ & - & 0.0001 \\
Total Fiber & 1.8 & 0.00 & - & \\
Calories & 437 & 688 & 900 & \\
\hline
\end{tabular}

aDeterminations were made by triplicate.

b Means followed by the same letter within each row are not significantly different at $P<0.05$. Duncan test.

c Means followed by the same letter within each row are not significantly different at $\mathrm{P}<0.05$. Student test.

the peroxide value. PM, CM and $\mathrm{O}$ showed significant differences in peroxide values at the beginningoftheexperience(day0)(TablelV).Atthe end of the heat treatment (day 7) the stability was similarforthethreeproducts $(55.67,51.3$ and59.33 $\mathrm{meqO}_{2} / \mathrm{Kg}$ ).

It is difficult to modify dietary habits when they are determined by multiple and complex factors involving social, economic and cultural aspects. Nevertheless, the elaboration of nutriments that are similar to the traditional ones but possessing improved nutritional properties and that are accepted by the population, seems to provide a viable alternative (FAO, 1992). In this regard, the sensorial evaluation made by the panel of adolescent consumers (between 18-20 years old) showed that PM was accepted by $71.7 \%$ of them (Table V).

Table II

Content of nutriments of a portion ( $30 \mathrm{~g}$ ) of "peanut mayonnaise" (PM), standard commercial mayonnaise $(\mathrm{CM})$ and sunflower oil $(0)$ regarding to the recommendations for the normal diet of an adult (2000 cal)

\begin{tabular}{lcccc}
\hline \multirow{2}{*}{ Nutriment } & Daily nutr. & \multicolumn{3}{c}{ Percentage covered by 30 g } \\
\cline { 3 - 5 } & Recommend. & P M & C M & O \\
\hline Carbohydrates & $250-300 \mathrm{~g}$ & 0.75 & 0.17 & - \\
Proteins & $55-75 \mathrm{~g}$ & 2.67 & 0.33 & - \\
Fiber & $20-25 \mathrm{~g}$ & 2.4 & - & 45 \\
Fats & $66,6 \mathrm{~g}$ & 19.3 & 34.6 & 13.5 \\
Calories & 2000 & 6.5 & 10.32 & \\
\hline
\end{tabular}

All experiments were made by triplicate. 
Table III

Fatty acid composition of "peanut mayonnaise" (PM), standard commercial mayonnaise (CM) and sunflower oil $(0)$

\begin{tabular}{|c|c|c|c|c|}
\hline \multirow{2}{*}{ Fatty Acids } & \multicolumn{3}{|c|}{ Percentages (wt\%) } & \multirow{2}{*}{$P$ value } \\
\hline & PM & CM & 0 & \\
\hline \multicolumn{5}{|l|}{ SFAs } \\
\hline 16.0 & 6.0 & 6.2 & 5.5 & \\
\hline 18.0 & 1.6 & 2.1 & 1.7 & \\
\hline 20.0 & 0.4 & - & - & \\
\hline 22.0 & 1.3 & - & - & \\
\hline 24.0 & $\operatorname{Tr}$ & - & - & \\
\hline$M^{a}$ & $9.3 a$ & $8.3 b$ & $7.2 \mathrm{c}$ & 0.0027 \\
\hline \multicolumn{5}{|l|}{ MUFAs } \\
\hline 18.1 & 29.2 & 20.8 & 25.5 & \\
\hline 20.1 & 0.6 & - & - & \\
\hline$M^{a}$ & $29.8 \mathrm{a}$ & $20.8 \mathrm{~b}$ & $25.5 \mathrm{c}$ & 0.0000 \\
\hline \multicolumn{5}{|l|}{ PUFAs } \\
\hline 18.2 & 61.0 & 70.9 & 67.4 & \\
\hline$M^{a}$ & $61.0 \mathrm{a}$ & $70.9 b$ & $67.4 \mathrm{c}$ & 0.0001 \\
\hline $0 / L$ & 0.5 & 0.3 & 0.4 & \\
\hline
\end{tabular}

All experiments were made by triplicate. Abbreviations: $\mathrm{SFAs}=\mathrm{sa}-$ turated fatty acids; MUFAs = monounsaturated fatty acids; PUFAs = polyunsaturated fatty acids; $\mathrm{O} / \mathrm{L}=$ oleic acid/linoleic acid ratio; $\mathrm{Tr}$ = trace; $\mathrm{M}=$ arithmetic Mean.

a Means followed by the same letter within each row are not significantly different at $\mathrm{P}<0.05$. Duncan test.

The challenge for the industry resides in offering products that can respond to the guidelines of a healthy nutrition. As a dressing, PM has a relatively reduced content of fats and calories, is poor in sodium, cholesterol-free and besides, it contains other nutriments, such as vitamins, minerals and fibers. These properties added to an adequate lipid profile converts "peanut mayonnaise" in a more complete dressing than standard commercial mayonnaise and sunflower oil suitable for consumption by the general population, and perhaps by people with certain pathologies like diabetes, obesity, hypertension and dyslipidemias.

\section{ACKNOWLEDGMENT}

This work was supported by CONICET, CONICOR and SECYT.

\section{REFERENCES}

Ahmed, E. H. and Young, C. T. (1982). Composition nutrition and flavor of peanut in Peanut Science and
Table IV

Peroxide values of "peanut mayonnaise" (PM), standard commercial mayonnaise (CM) and sunflower oil (0)

\begin{tabular}{ccccc}
\hline \multirow{2}{*}{ Days } & \multicolumn{3}{c}{ Peroxide value $\left(\mathrm{meq} . \mathbf{0}_{2} / \mathbf{k g}\right)^{\mathrm{a}}$} & \multirow{2}{*}{ p value } \\
\cline { 2 - 4 } & $\mathbf{P ~ M}$ & $\mathbf{C ~ M}$ & $\mathbf{0}$ & \\
\hline $0^{\mathrm{b}}$ & $5.67 \mathrm{a}$ & $5.33 \mathrm{a}$ & $2.00 \mathrm{~b}$ & 0.0001 \\
\hline 2 & $1500 \mathrm{a}$ & $1667 \mathrm{a}$ & $1300 \mathrm{c}$ & 0015 \\
4 & $25.67 \mathrm{a}$ & $26.67 \mathrm{a}$ & $28.67 \mathrm{a}$ & 0.178 \\
7 & $55.67 \mathrm{a}$ & $51.33 \mathrm{~b}$ & $59.33 \mathrm{c}$ & 0.023 \\
\hline
\end{tabular}

a On a fresh basis. All experiments were made by triplicate. b Means followed by the same letter within each row are not significantly different at $P<0.05$. Duncan test.

Table V

Consumer analysis of "peanut mayonnaise" according to a hedonic scale where points 5 and 4 are pleasure opinion, point 3 is indifference opinion and points 2 and 1 are disgust opinion

\begin{tabular}{cc}
\hline Opinions & $\%$ of consumers \\
\hline Pleasure & 71.7 \\
Indifference & 18.9 \\
Disgust & 9.4 \\
\hline
\end{tabular}

Technology, 655-687. H.E. Pattee and C.T. Young (Eds.). American Peanut Research and Education Society, Inc., Yoakum, Texas.

Anzaldua-Morales, A. (1994). Las pruebas sensoriales in La evaluación sensorial de los alimentos en la teoría y en la práctica, 67-117. Ed. Acribia SA, Zaragoza, España.

AOAC Methods (1980). Official Methods of Analysis. $13^{\text {th }}$ ed. Association of Official Analytical Chemists.Washington D.C.

AOAC (1990). Official Methods of Analysis. $15^{\text {th }}$ ed. Association of Official Analytical Chemists. Arlington, Virginia, USA.

Araya A. J. (1996). Lípidos in Nutrición y Salud, 45. 1ra Ed. Ruiz O.M. y col. Eds. Dpto. Nutrición, Fac. de Medicina, Universidad de Chile, Santiago de Chile.

Cicchitti, L. F. (1996). Dieta y aterosclerosis. Revista de la Sociedad Argentina de Nutrición 7, 5-15.

CIARA. (2000). Cámara de la Industria Aceitera de la República Argentina. Anuario Estadístico de Oleaginosos 1999, Buenos Aires, Argentina, p. 1-180.

Dixon, L. B. and Ernest, N. D. (2001). Choose a diet that is low in saturated fat and cholesterol and moderate in total fat: subtle changes to a familiar message. J. Nutr. 131, 510-526.

Food and Nutrition Board (1989). National Academy of Sciences. National Research Council. Recommended Dietary Allowances. 10 th Ed. Washington, DC: National Academy Press. 
FAO (1992).Conferencia internacional sobre nutrición: "Elementos principales de estrategias nutricionales". Fomento de dietas y estilos de vida sanos.Documento Temático Nro. 5. Roma, 1-30.

Grosso, NR and Guzmán, CA. (1995). Chemical Composition of Aboriginal Peanut (Arachis hypogaea L.). Seeds from Perú. Journal and Food Chemistry 43,102-105.

Harvez, J. (1996). Informe sobre "Análisis y perspectivas de comercialización de maní 1995/1996". Dirección de Mercados Agrícolas y Agroindustriales-SAPyA, 1-13.

Jellum, M.D. and Worthington, R.E. (1966). A rapid method of fatty acid analysis of oil from individual corn (Zea mays L.) kernels. Crop Sci. 6, 251-253.

Keefe, S and Willey, V. (1993). Comparison of oxidation stability of high and normal oleic Peanut Oils. J. Am.Oil Chemist's Soc. 70, 489-92.

Krauss, RM; Deckelbaum, RJ; Ernst, N.; Fisher, E.; Howard, BV.; Knopp, RH.; Kotchen, T., Lichtenstein, AH.; McGill, HC.; Pearson, TA.; Prewitt, TE.; Stone NJ.; Van Horn L. and Weinberg, R. (1996). Dietary Guidelines For Healthy American Adults. AHA Medical/Scientific Statement 94, 1795-1800.

Mahan, LK y Arlin, MT. (1996). Lípidos, Nutrición y Dietoterapia, 45. 8va. Ed.Interamericana McGraw-Hil (Eds), Healthcare Group.

Maldonado, EM y Guzmán, CA (1982). Contenido en algunos elementos y cenizas totales en semillas de nueve cultivares de maní de la provincia de Córdoba (Argentina). фyton 42(2), 185-189.
Mattson, FH, Grundy, SM. (1985). Comparison of effects of dietary saturated, monounsaturated, and polyunsaturated fatty acids on plasma lipids and lipoproteins in man. J. Lipid Res. 26, 194-202.

Mensink RP and Katan MB. (1992). Effects of dietary fatty acid on serum lipids and lipoproteins: A meta-analysis of 24 trials. Arteriosclerosis and Thrombosis 12, 911-919.

Olivares C., S. (1996). Alimentación Saludable. Programa de salud cardiovascular. Ministerio de Salud. Capítulo 1, p. 5.-Ed. Dr. Carlos Castillo M. Universidad de Chile. Chile.

FAO/WHO (1997). Fat and oils in human nutrition. Report of a joint expert consultation. Rome 57(3-7), 65-71.

Organización Panamericana de la Salud. Argentina: Análisis de la Situación de la Salud y Tendencias.-(2000). Organización Mundial de la Salud. Washington, DC. Publicación Científica, Vol. 21, 26-39.

Raats, S. K., Bibus, D., Thomas, W. and Kris-Etheton, P. (2001). Total fat intake modifies plasma fatty acid composition in Humans. J. Nutr. 131, 231-234.

Universidad de Granada. 1995. Tabla de composición de alimentos españoles. Instituto de Nutrición y Tecnología de Alimentos. 2da. Ed. Granada.

Young, C.T. and Harnmons, R.O. (1973). Variations in the protein levels of a wide range of peanut genotypes (Arachis hypogaea L.). Oleagineux 28, 293-297.

Recibido: Junio 2001 Aceptado: Mayo 2002 